\title{
Tensions in the concept of constitution due to the colombian's peace process
}

\section{Tensões no conceito de constituição devido para o processo de paz da Colômbia}

\author{
Yenny Andrea Celemín Caicedo. ${ }^{1}$
}

\begin{abstract}
:
This paper analyses the effect of the different perspectives in the Colombian constitutionalism about the Peace Process Final Agreement, reached between the government and the Farc guerrilla to end the armed conflict. Particularly, the enactment of the Special Legislative Peace Process (SLPP), a fast-track procedure developed to implement the new normative framework based on the peace agreement, is studied. We argue that this normative piece, in practice, acts as a device that embodies the role that diverse actors have given to the concept of the Constitution. Despite, of the arguments elaborated to justify the enactment of the constitutional amend that incorporated the SLPP to the Colombian Constitution, this essay show that there is still a deep disagreement about the meaning of the Constitution in opposing sectors of the Colombian society, in which some sectors perceive the Constitution as a rigid limit, whereas others see it as breakable wall.
\end{abstract}

${ }^{1}$ Yenny Andrea Celemín Caicedo.Professor in the Law department, Jorge Tadeo Lozano University, Bogotá, Colombia. PhD in Law, Andes University, Colombia. Email. yennya.celeminc@utadeo.edu.co. 
Key words: Colombian Peace Process; Regular legislative process; Special Legislative Peace Process; Constitutional limits meaning.

\section{Resumo:}

Este artigo analisa o efeito das diferentes perspectivas no constitucionalismo colombiano sobre o Acordo Final do Processo de Paz, alcançado entre o governo e os guerrilheiros das Farc para acabar com o conflito armado. Em particular, é estudada a promulgação do Processo Legislativo Especial de Paz (SLPP), um procedimento acelerado, desenvolvido para implementar o novo quadro normativo baseado no acordo de paz. Nós argumentamos que essa peça normativa, na prática, age como um dispositivo que incorpora o papel que vários atores têm dado ao conceito de Constituição. Apesar disso, dos argumentos elaborados para justificar a promulgação da alteração constitucional que incorporou o SLPP à Constituição colombiana, este ensaio mostra que há ainda um profundo desacordo sobre o significado da Constituição em sectores opostos da sociedade colombiana, nos quais alguns dos setores percebem a Constituição como um limite rígido, enquanto outros a vêem como uma parede quebradiça.

Palavras-chave: Processo de paz colombiano; Processo legislativo regular; Processo Legislativo Especial de Paz; Significado dos limites constitucionais.

\section{Introduction}

One of the basic principles on which modern constitutionalism is grounded is the understanding of constitutions as the limits to constrain political power. These limits are different in their essence and shape. They can be organic, procedural as well as substantive boundaries for the state's authority. Regardless their diversity, they usually operate in a regular and stable manner; in a way that authors such as Ackerman have labeled as moments of normal politics (ACKERMAN,1999, p.186). 
However, it is possible to recognize alternative moments categorized as moments of constitutional politics (ACKERMAN 1999, p.185), in which the limits imposed by the Constitution are reappropriated by political power. Under these circumstances, the continuity of certain rules, institutions, procedures, or even certain substantive contents of the Constitution are regarded as obstacles to achieve a transition from a particular social order to a new one. When this happens, the notion of constitutionalism acquires a new facade. The constitutional law is no longer considered to be a rigid or immutable limit that those who embrace power must abide by.

In moments of constitutional politics, the existing constitution is perceived as a barrier that must be overridden. A wall built up on which certain holes are left. Holes through which political power permeates the old institutions and procedures to transform them: "The Constitutions are usually born in moments of crisis, to solve some fundamental political-social drama." (GARGARELLA y COURTIS, 2009, p.10).

Nevertheless, this classic representation that divides constitutionalism in moments of normal politics and moments of constitutional politics omits an issue that, in the context of contemporary societies, is becoming a relevant question. This issue has been tagged as the circumstances of politics by some authors in the legal field (WALDRON, 2005), and as pluralism by some others in political science (DAHL, 1992).

The idea of the circumstances of politics or pluralism can be summarized as it follows: political power scarcely corresponds to a homogeneous force; a force that acts harmoniously based on the impulse provided by the consensus about the solutions that a society must adopt to face its "fundamental, political-social dramas". On the contrary, these solutions are different in each society, and they depend on diverse necessities, interests or desires that the people compounding the society have.

When the concept of political power is outlined more closely to the idea of the circumstances of politics or pluralism, tensions regarding the type of constitutional moment being faced with can emerge. These tensions unveil diverse positions; points of view claiming for different meanings to the constitution concept.

The Colombian political system is currently experiencing one of these moments of tension (PULIDO y BUSTOS, 2016). The adoption of the Special Legislative Process for 
Peace can be framed as a sample of the disagreements related to the type of political moment that the Colombian society is enduring as well as the ones related to the role that the Constitution plays apropos of political power.

Thus, a part of the Colombian society has supported the emerging of a constitutional moment resulting from the peace agreement implementation between the Colombian government and the FARC-EP ${ }^{2}$ for ending the armed national conflict. On the other hand, another part with equal breadth of influence is completely opposed to understanding the political moment that Colombia is facing. For the latter, the way to legitimize the peace process is by the normal politics reasoning. If so, the limits imposed by the Constitution must be respected in incorporating the peace agreement in the juridical system to guarantee the stability and durability of the changes proposed to the social-political institutions.

The purpose of this essay is to describe the way in which the current political tension has been developed in the Colombian constitutional sphere. In this line of thinking, this paper will analyze the deliberations originated around the creation of the Act 01of 2016. A constitutional amendment that introduces a fast-track procedure for enacting a set of new laws on the basis of the peace agreement.

\section{Contextualization}

After many attempts to end the internal armed conflict between the Colombian state and the insurgent revolutionary group FARC-EP, President Juan Manuel Santos' delegation began the negotiation process to bring an end to the Colombian conflict in 2011. The peace dialogs between the government delegates, the guerrilla senior members and the international community took place in Havana (Cuba).

The negotiation process results were compiled in a final-agreement document ${ }^{3}$ which was signed in Havana on June 26, 2016 and signed again in Colombia on November 20 of the same year.

\footnotetext{
${ }^{2}$ Fuerzas Armadas Revolucionarias de Colombia - Ejército del Pueblo Revolutionary Armed Forces of Colombia - People's Army

${ }^{3}$ Colombia's Final Agreement to end the armed conflict and build a stable and lasting Peace. Available in http://www.altocomisionadoparalapaz.gov.co/Paginas/inicio.aspx
} 
This document reflects the FARC-EP members' will to reincorporate themselves into civilian life under the understanding that it is necessary to modify some aspects of the legal system as well as some others at the economic, political and social levels in Colombia. Such changes allow the guerrilla to participate in democratic life and enable Colombians to gain peace on account of the end of the conflict.

Urgent mechanisms based on the following topics were integrated to the peace accord: (i) the agrarian development by the implementation of a comprehensive rural reform; (ii) the reconfiguration of democratic institutions to authorize political participation to FARC members, and to expand the political scenarios from representative scenarios to social movements, (iii) the agreements on bilateral and definite ceasefire and the cessation of hostilities, and the reincorporation of the FARC-EP into civilian life; (iv) the strategy to combat drug trafficking (vi) the consideration of criminal offences that are eligible for amnesty or pardon and mechanisms of transitional justice.

Due to the relevance and diversity of subjects that constitute the agreement, it was necessary to start planning institutional reforms in different areas such as the legal, political, and electoral systems, rural institutions, among others.

Thus, while the negotiation for peace between Juan Manuel Santos' cabinet and the guerrilla took place, the Colombia Congress drafted a new constitutional amend to develop legal instruments to facilitate the normative framework implementation subject to the Final Agreement. Such amend is called Legislative Act 01 of 2016. It is a reform that will allow legislative procedures to ease off as it permits to elaborate new legislation by fast-tracking it.

In this sense, the Legislative Act 01 of 2016 creates a special legislative procedure named Special Legislative Process for Peace (henceforth SLPP), exclusively for the peace agreement normative framework. The SLPP has some features for doing quicker legislation and constitutional amendments related whit it.

Firstly, the SLPP reduces the number of debates that must be done for a piece of legislation to become a law. Moreover, The SLPP cuts down the time that the Colombian 
Constitutional Court must do judicial review of the legislation enacted through this especial procedure.

Secondly, the SLPP is faster than the ordinary legislative process, not just because of the reduction of floor discussions, but because it prioritizes legislations related to the peace agreement in the legislative agenda. In consequence, the Congress must discuss these legislative drafts before it discusses any other legislative matter.

Thirdly, the SLPP affects the capacity of congressmen to represent their constituencies. Thus, it determines that only the Government can introduce any draft legislation related to the peace agreement. This narrowing of the congressional representation capacity is also reflected on the need for permission or governmental endorsement for any changes the Congress wants to make to the normative framework elaborated in the peace agreement ${ }^{4}$.

All these transcendental transformations to the regular legislative process established in the Constitution of 1991 created a scenario for a fight about the political moment that Colombia is experiencing due to the negotiation between the guerrilla and the government. In the next sections, I will describe the way in which this battle occurs in the Colombian context.

\section{The Endorsement of a Moment of Constitutional Politics by the Implementation of the SLPP: the Constitution as a Breakable Wall.}

The Act 01 of 2016 contains a set of special measures to create the normative framework for the peace agreement. Discussions on this Act began on September 15, 2015 and it culminated on July 7, 2016. The Colombian Government introduced the draft of the Constitutional amendment. However, it is important to point out that the draft was endorsed by more than forty congressmen belonging to the political forces supporting the peace process. Some justifications for the project are found in the explanatory memorandum

\footnotetext{
${ }^{4}$ This feature of the SLPP was declared unconstitutional by the Colombian Constitutional Court in C-331/17 rule, which will be depicted below in this paper.
} 
attached to this initiative (CONGRESO DE COLOMBIA, Gaceta No 706, septiembre 15 de 2015, p. 2):

$\mathrm{Y}$ en tercer lugar, porque en todas las negociaciones es determinante proveer garantías de que lo que se acuerde en efecto se va a cumplir. No será posible dispone de un mecanismo creíble para convencer a la contraparte de que el desarrollo normativo será fiel a lo acordado y que se respetará la palabra empeñada.

The draft amend initially contained just two special and transitional clauses about the peace agreement implementation. The first one established the terms, validity and characteristics of the SLPP. The second one gave exceptional legislative power to the Colombian President for making legislation by decree in these kinds of matters.

Nonetheless, after eight debates on the first draft legislation took place in the legislative chambers, the outline of the original project was transformed. These transformations were made after the dialogs between government members, congressmen and the parliamentary groups compounding the Colombian Congress.

The process culminated with the adoption of a constitutional amendment made up of five articles mainly related to: (i) the description of the SLPP, (ii) the specification of the funding sources for the peace agreement implementation and (iii) the terms of validity of the amend ${ }^{5}$.

Despite the differences among supporters of the Act 01 of 2016, they have a common view for justifying the changes proposed to the Constitution; the necessity to be prepared to make all the institutional modifications required for all the contents of the agreements reached by the government and the guerrilla.

The peace supporters highlighted the importance of avoiding the resurgence of violence because of delays in the peace agreement implementation. They were conscious of the magnitude of the changes to be made, but they also emphasized that some guaranties or safeguards were necessary to avoid excesses in the use of the SLPP.

\footnotetext{
${ }^{5}$ According to the art. 5 of the 01 of 2016 Legislative Act: the SLPP will begin to have validity, after popular approval. What means the expression popular approval was one of the tension about SLPP that will be described in this paper.
} 
Firstly, the SLPP was designed as a transitory legislative process that could be used for only six months and be renewable for six more months.

Secondly, the normative framework enacted by the SLPP was going to be reviewed by the Colombian Constitutional Court to guarantee the institutional reforms are subject to the constitutional frame.

Thirdly, Colombian citizens should endorse the SLPP by plebiscite as stated in the Act 1806 of $2016^{6}$ which called such plebiscite to know the conformity of the Colombian people with the contents of the peace agreements. (CONGRESO DE COLOMBIA, Gaceta No 776, Octubre 2, 2015).

All these safeguards were exposed in the debates by the peace supporters who also focused on the existence of an exceptional moment for ending the Colombian armed conflict. One of the members of the Liberal party stated the following reflection on this topic in the fifth-floor discussion of the Act 01 of 2016(CONGRESO DE COLOMBIA, Gaceta No 113, marzo 30 de 2016, p.41.):

\begin{abstract}
Muy breve señor Presidente, quisiera intervenir en mi calidad de ponente en la discusión de este proyecto para a manera de constancia dejar algunas reflexiones, la primera de ellas tiene que ver con la circunstancia excepcional que estamos viviendo en medio del trámite y la discusión de este proyecto, no es lo mismo abordar esta reforma constitucional en un ambiente de normalidad, si no que estamos buscando en un proceso de paz ponerle fin a más de 50 años de conflicto armado interno a través de un proceso de negociación y de un proceso de paz que ya está muy avanzado en su fase prácticamente final y por eso esta circunstancia de excepcionalidad pues genera que estudiemos un acto legislativo como este que también es excepcional en esa circunstancia.
\end{abstract}

\footnotetext{
${ }^{6}$ In the 1806 of 2016 Act, the Colombian Congress approved a plebiscite as the mechanism to validate the final agreement by the People. It is important to highlight that this act, also created special provisions for realizing this plebiscite. Thus, while in an ordinary plebiscite, according with the 1757 of 2015 Act, it is necessary a participation of the $50 \%$ of the Colombian electoral census for counting votes as valid votes, in the 1806 of 2016 Act this rule was changed. In this piece of legislation, the approval of the final agreement depended of the approbation or rejection of the $13 \%$ of the electoral census.
} 
In this view, the exceptional moment for ending the conflict justified to cross the limits imposed by the 1991 Colombian Constitution to change old institutions by means of the SLPP.

However, the constitutional limits crossed by the SLPP were considerable. First, the SLPP reduces the number of floor discussions that any constitutional amend must undergo from eight to four, therefore the second reading stage is eliminated.

Nevertheless, the most important limitation that was overcome by the SLPP was related to Judicial Review. Indeed, the article forty of the Colombian Constitution grants the fundamental right to the Colombian citizens to start a law case against a legislation if it is contradictory to constitutional statements or principles. Yet exercising such a right was seriously limited by the legislation enacted through the SLPP. Therefore, the Colombian citizenry could not bring any lawsuit against the legislation enacted by the SLPP implementation. Despite the above, this new legislation will directly be reviewed by the Constitutional Court of Colombia.

This exceptional and novel transformation was supported by the pro peace sector pleading the necessity to make stable the normative framework created for the peace agreement implementation. (CONGRESO DE COLOMBIA, gaceta No.488, 18 de mayo de 2016, p.85)

From this point of view, the importance of this political moment justified the creation of special and exceptional legislative procedures to achieve the transformations required to incorporate the Peace Agreements in the Colombian legal system.

In this manner, because of the emergence of a moment of constitutional politics, the role of the Constitution cannot be considered as a limit for exercising the derivative power for legal creation or amend. In other words, the Constitution is a means to facilitate a transition which permits to reconfigure political power.

\section{The Endorsement of a Moment of Normal Politics: the Constitution as a Rigid Limit for the Peace Agreement}

On the other hand, other positions claim for an opposite sense for the concept of Constitution. They emphasized the importance of recognizing this period as a moment of 
normal politics. They stated the role of the Constitution is to limit the power to make amends. In consequence, they rejected the enactment of the Act 01 of 2016, and they also opposed accepting the SLPP as a valid mechanism for fast-tracking the normative framework of the peace agreement.

For the opposition, the SLPP gives several prerogatives to the Executive Branch, which results in imbalance of power between this branch and the legislative one. Put differently, the Legislative Branch was relegated to a secondary role in the peace process, despite transcendental institutional changes are to be made due to the agreements.

In addition, the reduction in the number of floor discussions for delicate matters such as transitional justice, political system, rural property, and the like could result in very bad legislations, threatening the stability of major social and economic issues.

Moreover, this sector condemns the modifications in the judicial review introduced in the SLPP. Regarding such modification, one of the congressmen of Centro Democrático, the political party which opposed the negotiation for peace between the Government and the Guerrilla, said (CONGRESO DE COLOMBIA, Gaceta No 488, mayo 18, 2016, p. 68):

Y ¿Qué nos dice sobre el control constitucional? Que va a ser solo uno, va a ser un control único y automático y deja por supuesto el resto de los controles por fuera, controles por vía de acción como la acción pública por inconstitucionalidad, los actos reformatorios de la Constitución, la acción de nulidad por inconstitucionalidad, la acción pública de nulidad, la acción de tutela, el control previo, el control por vía de excepción, no hay ninguna posibilidad de hacerle algún tipo de control a esta incorporación de lo recetado por los terroristas de La Habana.

The opposition has lately claimed for an understanding of the Constitution as an impassable limit. For them, the procedures to make constitutional amendments or legislation could not ease off to incorporate the SLPP. Put differently, eliminating the second reading stage for creating legislation or constitutional amends was unacceptable since it contradicts Colombia's legal system reasoning. According with its point of view, the Peace Agreements cannot precede the Colombian Constitution. 
Nevertheless, the opposition were the minority in the Colombian Congress. For that reason, their arguments were overshadowed by the justifications which those believing in the existence of a moment of constitutional politics stated.

Therefore, the peace-process supporters managed to modify the regular legislative procedures. These procedures were replaced by the SLPP which became the mechanism to assure the new institutional design for the Peace Agreement. All this was made conditional on the Colombians' approval to cause the SLPP to be valid.

\section{Appealing to the People's Will: the Colombian citizenry as Referees in the Battle}

The subsequent step was to call the Colombian people to a plebiscite organized two months after signed of the Peace Agreement. In such plebiscite, the citizens had to say whether or not they supported it by answering this question: Do you support the final agreement to end the conflict and build a stable and lasting peace?

The contest for approving the Act 01 of 2016 had started on the congress floor, but it was then moved to the streets and social media networks. Consequently, peace supporters and their contradictors move this polarization from the Congress to the ballot box.

However, the outcome turned out to be different in the plebiscite from it was in the Congress. The plebiscite narrowly failed: a 50.2\% share rejected the peace accord, while 49.8\% supported it. According to the resolution given by the Colombian electoral authority: “el plebiscito obtuvo una mayoría por la opción No con 6, 438,538 votos, contra 6, 382,901 votos obtenidos por la opción SI." (CONSEJO NACIONAL ELECTORAL, Resolución 014 de octubre 19 de 2016).

As the validity of the SLPP depended on apopular approval according with the last provision of the 01 of 2016 Act, the Congress and the Government could not use the SLPP anymore. For that reason, the government delegates and the FARC-EP had to rewrite the peace agreement and make changes to some of the clauses the contradictors did not agree with during the plebiscite campaign.

On November 29, 2016, the Colombian Congress decided to endorse the Peace Agreement with its corrections. This means the congress acted in behalf of the Colombian 
population, instead of calling a new plebiscite. For most of the Colombian congressmen, a constitutional moment like this would justify the replacing of the popular judgement. On the contrary, the minority condemned such action and accused the pro peace sector of supplanting people's will.

In sum, the Congress endorsed the Peace Agreement and the SLPP was put into implementation to create the normative framework for the peace process.

\section{The Role of the Constitutional Court of Colombia in the Dispute about the Normal/Constitutional Moment as a Consequence of the Peace Process}

The Constitutional Court of Colombia made an extra move to end the dispute on which moment the Colombian constitutionalism was experiencing: normal or constitutional politics. In rules C-699/16 and C-331/17, the Colombian Court developed its viewpoint about this dispute.

It is common to say, following a popular proverb, that one foot cannot stand on two boats. However, given the fact that the peace process has had a considerable and undeniable impact in the concept of constitution, the Colombian Court has stood on both sides defying such popular saying. Hence the Court has pleased both sides in recognizing the existence of both a moment of normal and constitutional politics.

In its first decision C-699/16 rule, the Constitutional Court of Colombia declared the SLPP to be constitutional after a lawsuit was brought against the Act 01 of 2016 by a Colombian citizen ${ }^{7}$. The plaintiff stated that such an act was unconstitutional.

According to this citizen, lessening the requirements to make constitutional amendments is a measure that substitutes the Constitution of $1991^{8}$. The elimination of the second reading

\footnotetext{
${ }^{7}$ The article 40 of the Colombian Constitution contains a fundamental right to all the Colombian citizens to bring lawsuits against legislation or constitutional amendments enacted against the Colombian Constitution: "Todo ciudadano tiene derecho a participar en la conformación, ejercicio y control del poder político. Para hacer efectivo este derecho puede: (...) 6. Interponer acciones públicas en defensa de la Constitución y de la ley".

${ }^{8}$ The substitution of the Constitution doctrine is a kind of judicial review of constitutional amendments, in which the Colombian Constitutional Court can declares a constitutional amendments as unconstitutional.
} 
stage to make constitutional amendments equates regular legislation with Constitutional norms. It threats the supremacy of the Constitution, and it also undermines the constitutional entrenchment clause.

In its rule, the Court rejected the arguments stated in the lawsuit, and it declared the constitutionality of the Act 01 of 2016. According to the Court's rule, there is no substitution of the Colombian Constitution with the SLPP, because it is a transitory mechanism. The judgment contains the following argument to justify the constitutionality of the SLPP(CORTE CONSTITUCIONAL DE COLOMBIA, sentencia C-699 de 2016, p. 72):

En contextos de transición de un conflicto armado hacia su terminación, la garantía de la "integridad" del orden constitucional que esta Corte debe guardar (CP art 241), implica examinar el principio de resistencia constitucional con una dosis de adaptabilidad que asegure la conservación de sus compromisos.

Thus, the Court ratified the constitutionality of the Colombian Congress' decision to create a special process for implementing the normative framework derived from the peace agreement. In this decision, the Court seems to support the side that believes in the existence of a constitutional politics moment due to the peace process.

Nevertheless, the Colombian Court enacted another rule with an opposite view about the constitutionality of the SLPP. In a second lawsuit brought by one of the

According to the constitutional substitution doctrine, the competence's scope of derivative constituent power is lesser than the competence's scope of the original constituent power. The latter has boundless authority for amending the constitution in contrast to the limited capacity of the former. Without this fundamental distinction in the interpretation of the word amend, the line between both constituent powers is blurred and threats the function a Constitution as a device to maintain social stability. For this reason, the power to make amendments conferred by the Colombian Constitution to the derivative powers cannot replace the whole Constitution nor replace essential elements which makes it what it is. According to the Colombian Constitutional Court, these powers only can be exercised by the original constituent power. (Corte Constitucional de Colombia, sentencia C-551 de 2003) 
parliamentarians who belongs to the political party that was against the peace process, the Colombian Court made different considerations about the rationality of the SLPP.

Once again, the lawsuit was based on the idea that the SLPP in the Act 01 of 2016 substituted the Colombian constitution. This time, the attack to the SLPP was not founded on the unconstitutionality of the amendment in threatening the constitutional entrenchment clause, but in threatening the principle of separation of powers. Therefore, the necessity of governmental endorsement required for this especial procedure to approve amendments proposed by members of the chamber constitutes, in the plaintiff's view, a transgression to the autonomy of the congressional representatives for debating the drafts tied to the peace process.

The Colombian Court acknowledges the plaintiff to be right, and in this occasion, declares the unconstitutionality of some parts of the Act 01 of 2016. In its rule, the Court considers that (CORTE CONSTITUCIONAL DE COLOMBIA, sentencia C-331 de 2017, p. 179):

En consecuencia, si las regulaciones que implementen el Acuerdo Final son de diferente índole y versan sobre aspectos disímiles del orden jurídico, se muestra abiertamente opuesto a un principio identitario de la Constitución que esas diferentes expresiones normativas queden atadas en su configuración a la decisión del Gobierno. Antes bien, lo que exige el régimen democrático es que, con el fin de dotar de los más altos grados de legitimidad y estabilidad al proceso de implementación, el Congreso esté en posibilidad de ejercer, de manera plena, las competencias que integran el eje axial de la función legislativa, en los términos explicados en esta sentencia. Este propósito es imposible de lograr cuando la introducción de modificaciones en una materia amplia y objeto de determinación, como es el Acuerdo Final, termina dependiendo exclusivamente de la voluntad del poder presidencial.

Then the Constitutional Court of Colombia says that the government must abide by the Constitution of 1991 in implementing the peace agreement and must follow it to the letter.

In sum, the Colombian Court agrees with the existence of both a moment of normal and constitutional politics because of Colombia's peace process. After both decision, the 
Court brought the situation into stalemate by acknowledging both sides to be right and postposing the resolution to the dispute of the concept of constitution.

\section{Conclusion}

This article describes the different stages of the dispute about the meaning of the Colombian Constitution because of the peace process, in different scenarios such as the Colombian Congress and the Constitutional Court of Colombia. It is possible to say that there is not clarity nor agreement about the type of constitutional moment that Colombia is living due to the negotiation between the President Santos's cabinet and FARC-EP guerrilla.

Moreover, the end of this fight is faraway, because of the upcoming congressional elections for the 2018 to 2022 term beginning in 2018. Due to the current political tension, the parliamentary groups might be reshuffled after the elections.

If the parliamentary groups supporting the peace accords is reduced after the upcoming congressional elections, the agreements reached in justice, rights to rural property, electoral system and so forth can be overridden by the regular legislative process for the making of legislations and constitutional amendments.

Colombian people's word will be final in determining the future of the Peace Agreement, and the durability and stability of the normative framework enacted by the SLPP.

\section{Bibliography}

DAHL Robert. La Democracia y sus Críticos. New Haven, Yale University Press, 1992. ELSTER Jon y SLAGSTAD Run. Constitucionalismo y Democracia, México, Colegio Nacional de Ciencias Políticas y Administración Pública, 1999. 
PULIDO Fabio y BUSTOS Geraldine. Momentos Constitucionales y poder de reforma. En Procesos Legislativos y Ordenamiento Constitucional: Abordajes Teóricos, Bogotá, editorial CAEL, 2016.

GARGARELLA Roberto y COURTIS Cristian. El nuevo constitucionalismo latinoamericano: promesas e interrogantes, CEPAL, Chile, 2009. Available in http://repositorio.cepal.org/bitstream/handle/11362/6162/S0900774 es.pdf?sequence=1\&is

Allowed=y

WALDRON, Jeremy. Derecho y Desacuerdos, Madrid, Marcel Pons, 2005.

Colombia's Final Agreement to end the armed conflict and build a stable and lasting Peace. Available in http://www.altocomisionadoparalapaz.gov.co/Paginas/inicio.aspx

Legislative Act $01 \quad$ of $2016 . \quad$ Available in http://es.presidencia.gov.co/normativa/normativa/ACTO\%20LEGISLATIVO\%2001\%20D EL\%207\%20DE\%20JULIO\%20DE\%202016.pdf

CONGRESO DE COLOMBIA, Gaceta No 776, Octubre 2, 2015.

CONGRESO DE COLOMBIA, Gaceta del Congreso No 113, marzo 30 de 2016.

CONGRESO DE COLOMBIA, Gaceta del Congreso No 488, mayo 18, 2016.

C-699/16 Colombian Constitutional Court http://www.corteconstitucional.gov.co/relatoria/2016/c-699-16.htm

C-699/16 Colombian Constitutional Court http://www.corteconstitucional.gov.co/relatoria/2017/C-331-17.htm

Resolución 014 de octubre 19 de 2016 del Consejo Nacional Electoral)

Recebido em: 17 de junhode 2017.

Aceito em: 5 de julo de 2017. 